\title{
Analisa perbedaan kinerja keuangan pada perusahaan Farmasi yang Terdaftar di BEI sebelum dan setelah pengumuman covid-19.
}

\author{
Yuslinda Nasution \\ yuslindanst12@gmail.com
}

Dosen Tetap Jurusan Manajemen FEB, Universitas Satya Negara Indonesia - Jakarta

\begin{abstract}
The purpose of this study is to find out if there are differences in financial performance in the time before covid and after covid 19. The population of this study is Pharmaceutical Companies listed on IDX in the period 2019-2020 before covid and after covid. With a sample of 10 companies in this study.The methods used is Paired t-test Sample. The results of this study are no differences in the variable Current Ratio (CR), Earning Per Share (EPS), Book Value (BV), Debt To Asset Ratio (DAR), Debt To Equity Ratio (DER), Return On Asset (ROA), Return On Equity (ROE), and Net Profit Margin (NPM). For the share price there is a significant difference
\end{abstract}

Keywords: Stock Price, Current Ratio, Earning Per Share, Book Value, Debt To Asset Ratio, Debt To Equity Ratio, Return On Assets, Return On Equity, and Net Profit Margin.

\section{PENDAHULUAN}

Kinerja Keuangan perusahaan merupakan alat ukur yang memberikan informasi mengenai perusahaan kepada investor yang akan menanamkan modal dalam bentuk saham di pasar modal. Menurut (Tandelilin:2017) Pasar modal yaitu pertemuan antara pihak yang memiliki kelebihan dana dan pihak yang membutuhkan dana.

Perusahaan sektor farmasi merupakan perusahaan yang terus berkembang dalam jangka panjang dan mempunyai peranan besar bagi masyarakat. Hal ini terus meningkat semenjak munculnya wabah virus corona (Covid-19), virus tersebut merupakan penyakit yang bermula dari kota Wuhan di China dan menyebar di seluruh dunia pada awal tahun 2020 , termasuk di Indonesia. Pandemi Covid -19 berdampak pada pergerakan harga saham perusahaan farmasi yang terdaftar di bursa efek.Harga saham merupakan unsur utama bagi investor untuk menentukan pilihan terhadap investasi karena akan berdampak pada nilai perusahaan.

Penelitian yang dilakukan oleh (Evi Kumala,et al : 2021) menjelaskan bahwa terdapat perbedaaan sebelum dan sesudah covid-19 pada rasio CR,ROA,TATO,ROE sebelum dan selama pandemi. Penelitian yang dilakukan (Viaranti, Handri : 2020) menjelaskan bahwa ROA, GPM , dan NPM menunjukan adanya perbedaan penurunan yang signifikan saat pandemi Covid-19 , sedangkan ROE mengalami peningkatan signifikan saat pandemi Covid-19 dengan alat analisis ROA. Penelitian yang dilakukan (Annisa Nadya : 2020) yang menjelaskan bahwa rasio profitabilitas NPM,ROA, dan OPM mengalami perbedaan penurunan saat sebelum dan sesudah pandemi Covid 19 pada perusahaan LQ45. Penelitian yang dilakukan (Roosdiana : 2020) yang menjelaskan bahwa NPM, DER dan ROA tidak terdapat perbedaan pada saat sebelum dan sesudah pandemi Covid 19

\section{KERANGKA PENELITIAN TEORITIS DAN HIPOTESIS}

Kinerja keuangan (Menurut Hery : 2015) yaitu suatu upaya untuk menganalisis efektivitas dan efisiensi perusahaan dalam mendapatkan laba atau keuntungan

Menurut (Ikatan Akutansi Indonesia (IAI) :2012) dalam jurnal (Dicky Hidayat : 2018) kinerja keuangan merupakan tingkat efektif manajemen dalam mengelola fungsi perusahaan dalam kinerja agar dinilai baik para investor. 
Kinerja keuangan menurut (Irham Fahmi:2015) merupakan analisis dalam menilai perusahaan apakah sudah menggunakan peraturan yang baik dan benar dalam keuangan

Menurut (Jogiyanto :2016) Harga Saham yaitu Harga yang terjadi di pasar bursa pada saat tertentu dan harga saham tersebut ditentukan oleh pelaku pasar. Tinggi rendahnya harga saham ini ditentukan oleh permintaan dan penawaran saham tersebut di pasar modal.

Menurut (Ramadhan et al : 2019) Harga saham merupakan nilai nominal dari kepemilikan seseorang atau badan dalam perusaahan pasar modal yang terjadi di Bursa Efek Indonesia.

Menurut (Syamsudin:2016) Current Ratio merupakan rasio yang sering digunakan dalam finansial perusahaan, current ratio dapat dilihat dengan menggunakan current assets dengan current liabilities. Perusahaan yang memiliki current ratio yang tinggi dinilai sebagai perusahaan yang memiliki likuiditas tinggi, karena dapat meningkatkan harga saham pada perusahaan tersebut.

Menurut (Munawir : 2010) DAR merupakan rasio antara total hutang dengan total aktiva. Apabila rasio DAR semakin kecil maka perusahaan dinilai semakin aman, Total Aktiva dinilai bagus apabila lebih besar dari total utang.

Debt To Equity Ratio merupakan rasio solvabilitas, Menurut (Sukmawati : 2017) merupakan rasio yang mengukur total utang pada struktur modal. Apabila DER memiliki nilai yang rendah maka para investor akan tertarik untuk membeli harga saham karena dinilai jumlah proporsi utang yang dimiliki perusahaan lebih kecil.

Menurut (Syamsudin : 2016) ROA adalah ukuran kemampuan perusahaan secara keseluruhan untuk menghasilkan laba dengan jumlah aktiva yang terdapat di perusahaan. Apabila ROA tinggi maka perusahaan diniilai dapat mengelola asset dengan baik dan memperoleh laba lebih banyak

Menurut (Hery : 2015) NPM adalah rasio yang digunakan untuk mengukur laba bersih dibagi penjualan. Apabila nilai NPM semakin tinggi maka hal ini dianggap baik karena laba yang dihasilkan juga semakin tinggi

Menurut (Fahmi:2015) Earning Per Share merupakan rasio laba yang dilihat dari laba bersih dibagi jumlah saham yang beredar. Apabila Earning Per Share nilainya tinggi, maka pendapatan perusahaan juga tinggi

Book Value merupakan nilai buku per lembar saham untuk melihat jumlah saham beredar dengan ekuitas yang dimiliki perusahaan. Book Value berfungsi sebagai pembanding antara nilai buku perusahaan dan harga saham di pasar modal. Apabila nilai saham di pasar modal dinilai lebih kecil dari Book Value perusahaan, maka harga saham dinilai murah dan Apabila nilai saham di pasar modal dinilai lebih besar dari Book Value perusahaan, maka harga saham dinilai mahal

\section{HIPOTESIS}

Penelitian ini akan melihat kinerja keuangan harga saham perushaaan farmasi sebelum dan setelah pengumuman covid 19, ditinjau dari Harga Saham dan rasio CR,DAR,DER,ROA,ROE,NPM,EPS, BV. Berdasarkan tinjauan pustaka dan penelitian terdahulu, maka dapat diajukan suatu hipotesis sebagai berikut :

Ho : Tidak terdapat perbedaan kinerja keuangan sebelum dan setelah pengumuman Covid 19

Ha : Terdapat perbedaan kinerja keuangan sebelum dan setelah pengumuman Covid

\section{HASIL PENELITIAN}

Analisis Deskriptif 
analisis deskriptif merupakan ringkasan sederhana dari sampel yang kita teliti. Ringkasan tersebut adalah ringkasan data angka statistik yang berisi angka minimum, maximum, mean, dan std deviasi

Analisis Deskriptif dapat dilihat dalam tabel sebagai berikut :

Tabel 1

Hasil Uji Deskriptif Sebelum Covid

Descriptive Statistics
\begin{tabular}{|l|l|l|l|l|l|}
\hline & $\mathrm{N}$ & Minimum & Maximum & Mean & Std. Deviation \\
\hline CRSEBELUMCOVID & 10 & .99 & 5.94 & 3.0038 & 1.54770 \\
EPSSEBELUMCOVID & 10 & .00 & 132.26 & 23.8211 & 42.21475 \\
BVSEBELUMCOVID & 10 & .00 & 1286.90 & 221.5498 & 394.76247 \\
DARSEBELUMCOVID & 10 & .13 & .64 & .3995 & .18658 \\
DERSEBELUMCOVID & 10 & .15 & 1.74 & .8327 & .60954 \\
ROASEBELUMCOVID & 10 & .00 & .23 & .0817 & .06630 \\
ROESEBELUMCOVID & 10 & .00 & .26 & .1220 & .07833 \\
NPMSEBELUMCOVID & 10 & .00 & .26 & .0856 & .07552 \\
HARGASAHAMSEBELUMC & 10 & 181.00 & 29000.00 & 4148.0000 & 8767.82056 \\
OVID & 10 & & & & \\
Valid N (listwise) & & & & \\
\hline
\end{tabular}

Sumber : Data diolah SPSS

Tabel 2

Hasil Uji Deskriptif Setelah Covid

Descriptive Statistics
\begin{tabular}{|l|l|l|l|l|l|}
\hline & $\mathrm{N}$ & Minimum & Maximum & Mean & Std. Deviation \\
\hline CRSESUDAHCOVID & 10 & .90 & 4.12 & 2.3395 & 1.12398 \\
EPSSESUDAHCOVID & 10 & .00006 & 185.41550 & 34.7483930 & 58.93242903 \\
BVSESUDAHCOVID & 10 & .00 & 1417.16 & 247.6377 & 435.46026 \\
DARSESUDAHCOVID & 10 & .16 & .75 & .4073 & .19365 \\
DERSESUDAHCOVID & 10 & .19 & 2.98 & .8579 & .83769 \\
ROASESUDAHCOVID & 10 & .00 & .24 & .0877 & .07228 \\
ROESESUDAHCOVID & 10 & .00 & .29 & .1285 & .09494 \\
NPMSESUDAHCOVID & 10 & .00 & .28 & .1084 & .07981 \\
HARGASAHAMSESUDAHC & 10 & 780.00 & 29000.00 & 4702.5000 & 8587.98038 \\
OVID & 10 & & & & \\
Valid N (listwise) & & & & & \\
\hline
\end{tabular}

Sumber : Data diolah SPSS

Tabel 3

Analisis Deskriptif Perbandingan Variabel Sebelum Dan Sesudah Covid

\begin{tabular}{|l|l|l|l|}
\hline \multirow{2}{*}{ Variabel } & \multicolumn{2}{|l|}{ Rata-rata } & \multirow{2}{*}{ Keterangan } \\
\cline { 2 - 3 } & Sebelum & Sesudah & \\
\hline CR & 3.0038 & 2.3395 & Menurun \\
\hline
\end{tabular}




\begin{tabular}{|l|l|l|l|} 
EPS & 23.8211 & 34.74839 & Meningkat \\
\hline BV & 221.5498 & 247.6377 & Meningkat \\
\hline DAR & 0.3995 & 0.4073 & Meningkat \\
\hline DER & 0.8327 & 0.8579 & Meningkat \\
\hline ROA & 0.0817 & 0.0877 & Meningkat \\
\hline ROE & 0.122 & 0.1285 & Meningkat \\
\hline NPM & 0.0856 & 0.1084 & Meningkat \\
\hline $\begin{array}{l}\text { HARGA } \\
\text { SAHAM }\end{array}$ & 4148 & 4702.5 & Meningkat \\
\hline
\end{tabular}

Sumber : Data diolah SPSS

Berdasarkan data dari Tabel 4.4 hasil output data variabel sebelum dan sesudah covid dengan menggunakan variabel CR, EPS, BV, DAR, DER, ROA, ROE, NPM dan Harga Saham.

Variabel CR mengalami penurunan, sedangkan variabel EPS, BV, DAR, DER, ROA, ROE, NPM, dan Harga Saham mengalami peningkatan.

\section{Uji Normalitas Data}

Uji normalitas data merupakan uji yang digunakan untuk melihat data apakah data tersebut termasuk data normal atau tidak.

Tabel 4

\begin{tabular}{|c|c|c|c|c|c|c|}
\hline & \multicolumn{3}{|c|}{ Kolmogorov-Smirnov $^{\mathrm{a}}$} & \multicolumn{3}{|c|}{ Shapiro-Wilk } \\
\hline & Statistic & Df & Sig. & Statistic & Df & Sig. \\
\hline CRSEBELUMCOVID & .123 & 10 & $.200^{*}$ & .960 & 10 & .788 \\
\hline CRSESUDAHCOVID & .172 & 10 & $.200^{*}$ & .933 & 10 & .476 \\
\hline EPSSEBELUMCOVID & .293 & 10 & .015 & .656 & 10 & .000 \\
\hline EPSSESUDAHCOVID & .321 & 10 & .004 & .665 & 10 & .000 \\
\hline BVSEBELUMCOVID & .288 & 10 & .018 & .620 & 10 & .000 \\
\hline BVSESUDAHCOVID & .285 & 10 & .021 & .631 & 10 & .000 \\
\hline DARSEBELUMCOVID & .212 & 10 & $.200^{*}$ & .890 & 10 & .172 \\
\hline DARSESUDAHCOVID & .234 & 10 & .129 & .929 & 10 & .434 \\
\hline DERSEBELUMCOVID & .290 & 10 & .017 & .850 & 10 & .059 \\
\hline DERSESUDAHCOVID & .270 & 10 & .037 & .742 & 10 & .003 \\
\hline ROASEBELUMCOVID & .169 & 10 & $.200^{*}$ & .916 & 10 & .321 \\
\hline ROASESUDAHCOVID & .151 & 10 & $.200^{*}$ & .917 & 10 & .335 \\
\hline ROESEBELUMCOVID & .120 & 10 & $.200^{*}$ & .971 & 10 & .896 \\
\hline ROESESUDAHCOVID & .197 & 10 & $.200^{*}$ & .923 & 10 & .379 \\
\hline NPMSEBELUMCOVID & .213 & 10 & $.200^{*}$ & .874 & 10 & .112 \\
\hline NPMSESUDAHCOVID & .237 & 10 & .118 & .889 & 10 & .164 \\
\hline HARGASAHAMSEBELUMCOVID & .457 & 10 & .000 & .452 & 10 & .000 \\
\hline HARGASAHAMSESUDAHCOVID & .469 & 10 & .000 & .465 & 10 & .000 \\
\hline
\end{tabular}

*. This is a lower bound of the true significance.

a. Lilliefors Significance Correction

Sumber : Data diolah SPSS 


\section{Uji Beda : Paired Sampel t-test}

Uji t berpasangan (paired $t$-test) adalah salah satu metode pengujian hipotesis dimana data yang digunakan untuk melihat apakah data terdapat perbedaan atau tidak. Sebelum melakukan uji paired sampel test yang harus dilakukan adalah melakukan uji normalitas data.

Jika hipotesis $<0.05$, maka Ha diterima

Jika hipotesis $>0.05$, maka Ho diterima

\section{Current Ratio}

Tabel 5.

Uji Paired Samples Test Current Ratio Sebelum Covid dan Sesudah Covid

Paired Samples Test

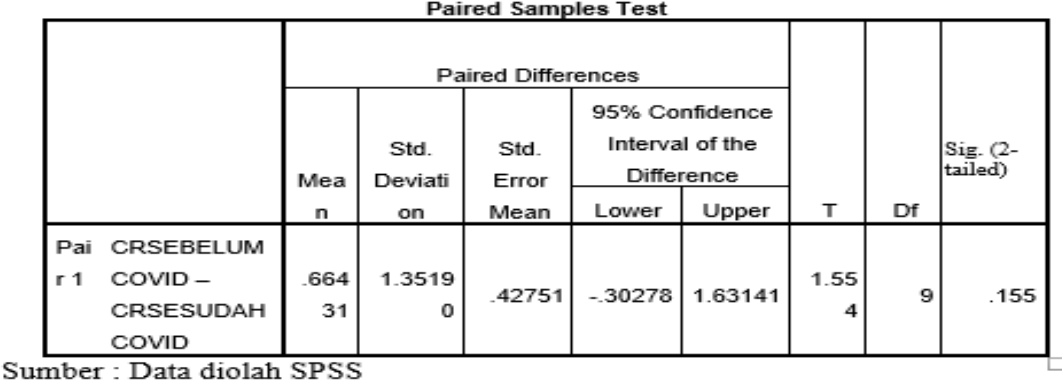

Dapat dilihat dari Tabel 5 Paired sample test, data diatas menunjukan angka signifikansi sebesar 0.155 angka tersebut lebih besar dari 0.05 . Kesimpulan dari data diatas adalah tidak terdapat perbedaan hasil test $\mathrm{CR}$ sebelum covid dan CR sesudah covid.

\section{Debt To Asset Ratio}

Tabel 6.

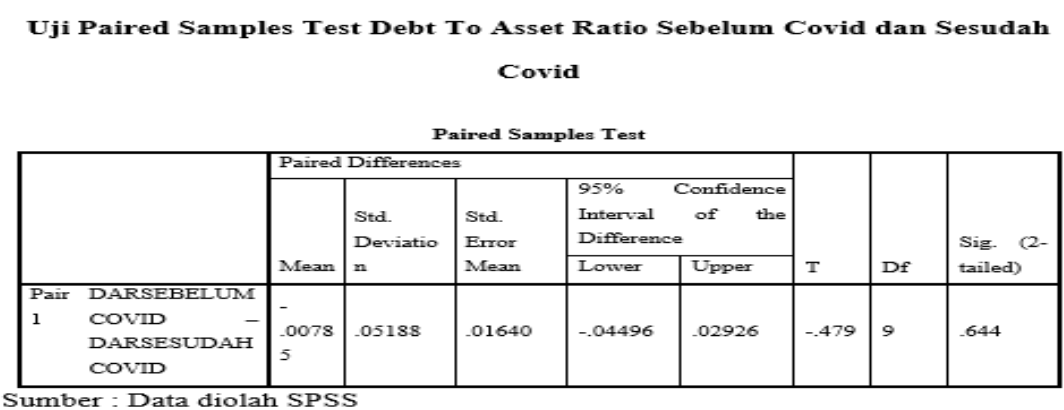

Dapat dilihat dari Tabel 6 Paired sample test, data variabel DAR diatas menunjukan angka signifikansi sebesar 0.644 angka tersebut lebih besar dari 0.05 . Kesimpulan dari data diatas adalah tidak terdapat perbedaan hasil test DAR sebelum covid dan DAR sesudah covid. 


\section{Return On Asset}

\section{Tabel 7}

Uji Paired Samples Test Return On Asset Sebelum Covid dan Sesudah Covic

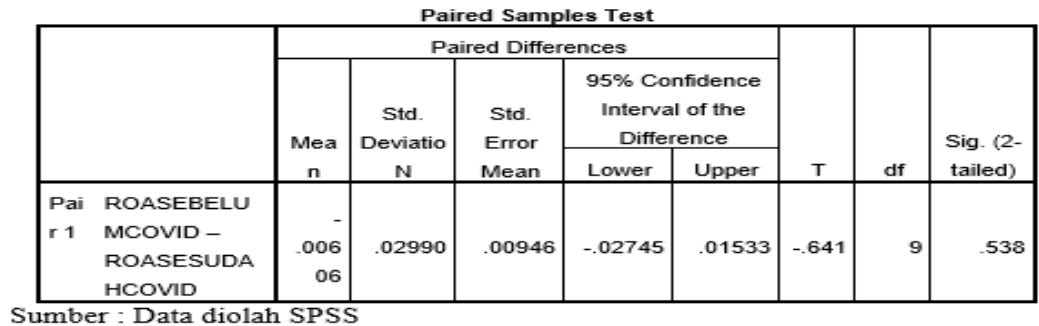

Dapat dilihat dari Tabel 7 Paired sample test, data variabel ROA diatas menunjukan angka signifikansi sebesar 0.538 angka tersebut lebih besar dari 0.05 . Kesimpulan dari data diatas adalah tidak terdapat perbedaan hasil test ROA sebelum covid dan ROA sesudah covid.

\section{Return On Equity}

Tabel 8.

Uji Paired Samples Test Return On Equity Sebelum Covid dan Sesudah

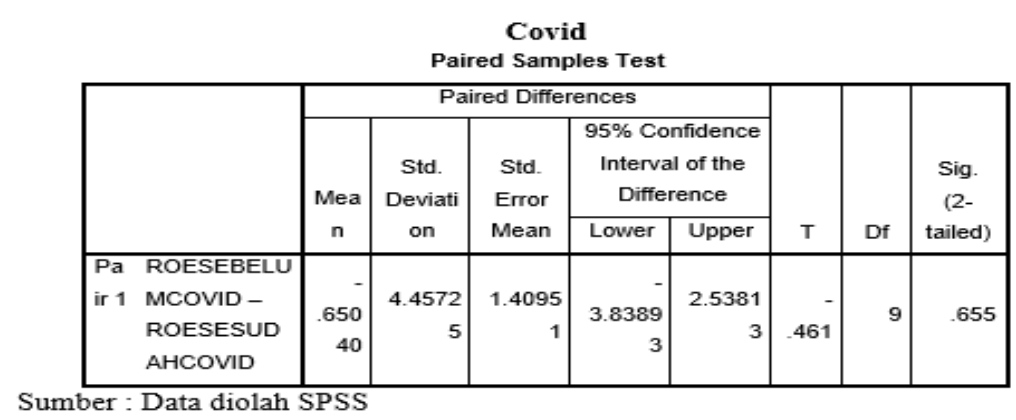

Dapat dilihat dari Tabel 48 Paired sample test, data variabel ROE diatas menunjukan angka signifikansi sebesar 0.655 angka tersebut lebih besar dari 0.05 . Kesimpulan dari data diatas adalah tidak terdapat perbedaan hasil test ROE sebelum covid dan ROE sesudah covid.

\section{Net Profit Margin}

\section{Tabel 9}

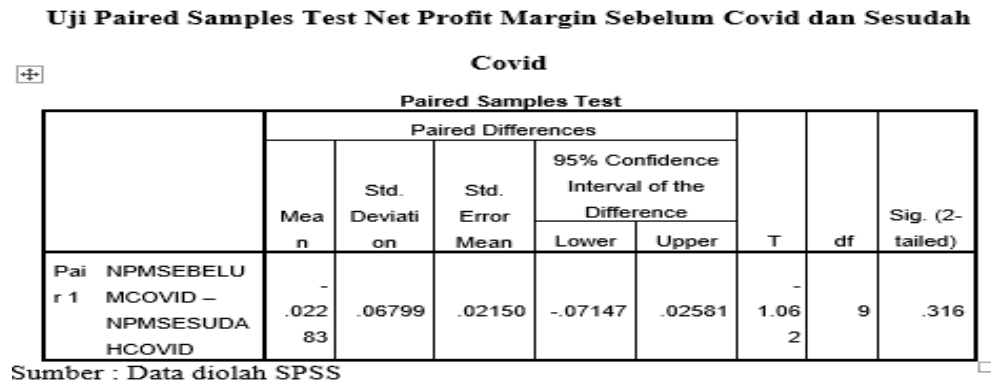

Dapat dilihat dari Tabel 9 Paired sample test, data variabel NPM diatas menunjukan angka signifikansi sebesar 0.316 angka tersebut lebih besar dari 0.05 . Kesimpulan dari data diatas adalah tidak terdapat perbedaan hasil test NPM sebelum covid dan NPM sesudah 
covid.

\section{Earning Per Share}

\section{Tabel 10}

Earning Per Share sebelum Covid dan Earning Per Sha
\begin{tabular}{|r|r|r|r|}
\hline \multirow{2}{*}{ EPS Sebelum } & EPS Sesudah & \multicolumn{2}{|c|}{ Selisih } \\
\cline { 3 - 4 } & 60.65635 & 29.36399 & $\%$ \\
\hline 31.29237 & 59.72512 & 5.58976 & 10.34 \\
\hline 54.13536 & 0.00368 & 0.00082 & 28.54 \\
\hline 0.00286 & 0.00006 & 0.00001 & 15.64 \\
\hline 0.00005 & 135.41550 & 53.15885 & 40.19 \\
\hline 0.17465 & 0.16050 & -0.01418 & -8.12 \\
\hline 17.46041 & 41.31039 & 23.84998 & 136.59 \\
\hline 0.19802 & 0.14471 & -0.05331 & -26.92 \\
\hline 2.56898 & 0.00969 & -2.55930 & -99.62 \\
\hline 0.121798 & 0.05793 & -0.06386 & -52.43 \\
\hline
\end{tabular}

\begin{tabular}{|l|r|r|}
\hline & eps sebelum & eps sesudah \\
Variance & 23.82111906 & 34.74839357 \\
Observations & 1782.084879 & 3473.031292 \\
Pearson Correlation & 10 & \\
Hypothesized Mean & 0.98692853 & \\
Difference & 0 & \\
Df & 9 & \\
tStat & -1.861678883 & \\
$P(T<=t)$ one-tail & 0.047778747 & \\
tCritical one-tail & 1.833112933 & \\
$P(T<=t)$ two-tail & 0.095557494 & \\
tCritical two-tail & 2.262157163 & \\
\hline
\end{tabular}

Sumber : Data diolah

Dapat dilihat pada Tabel 10 dari 10 tabel data variabel EPS, terdapat 6 data variabel EPS Setelah Covid mengalami kenaikan dibandingkan EPS Sebelum Covid. Berdasarkan perhitungan yang dilakukan maka diperoleh angka paired t-Test $0.095>0.05$. Kesimpulannya adalah tidak terdapat perbedaan antara Earning Per Share sebelum dan Earning Per Share setelah covid.

\section{Book Value}

Tabel 11

Book Value sebelum Covid dan Book Value Setelah Covid

\begin{tabular}{|c|r|r|r|}
\hline BV & \multirow{2}{*}{ BV Sesudah } & \multicolumn{2}{|c|}{ Selisih } \\
\cline { 3 - 4 } Sebelum & RV & \multicolumn{1}{|c|}{ RP } \\
\hline 171.38897 & 231.16921 & 59.78024 & 34.88 \\
\hline 356.38483 & 389.88874 & 33.50391 & 9.40 \\
\hline 1.33470 & 1.27938 & -0.05532 & -4.14 \\
\hline 0.00020 & 0.00021 & 0.00001 & 5.12 \\
\hline 1.286 .90 & 1417.16349 & 130.26661 & 10.12 \\
\hline 1.32592 & 1.36760 & 0.04168 & 3.14 \\
\hline 233.09784 & 294.59473 & 61.49689 & 26.38 \\
\hline 1.16614 & 1.18418 & 0.01804 & 1.55 \\
\hline 162.92086 & 138.84780 & -24.07306 & -14.78 \\
\hline 0.97811 & 0.88203 & -0.09607 & -9.82 \\
\hline
\end{tabular}

\begin{tabular}{|l|r|r|}
\hline & $B V$ sebelum & $B V$ sesudah \\
Mean & 221.5494454 & 247.6377382 \\
Observations & 155836.6678 & 189625.6392 \\
Pearson Correlation & 10 & 10 \\
Hypothesized Mean & 0.998605963 & \\
Difference & 0 & \\
Df & 9 & \\
t Stat & -1.785168116 & \\
$P(T<=t)$ one-tail & 0.053945915 & \\
tCritical one-tail & 1.833112933 & \\
P(T<=t) two-tail & 0.107891831 & \\
tCritical two-tail & 2.262157163 & \\
\hline
\end{tabular}

Dapat dilihat pada Tabel 11 Dari 10 tabel data variabel BV , terdapat 7 data variabel BV Setelah Covid mengalami kenaikan dibandingkan BV Sebelum Covid. Berdasarkan perhitungan yang dilakukan maka diperoleh angka paired t-Test $0.107>0.05$. Kesimpulannya adalah tidak terdapat perbedaan antara Book Value sebelum dan Book Value setelah covid. 


\section{Debt To Equity Ratio}

Tabel 12.

Debt To Equity Ratio Sebelum Covid dan Debt To Equity Ratio Setelah Covid

\begin{tabular}{|r|r|r|r|}
\hline \multirow{2}{*}{ DER Sebelum } & \multirow{2}{*}{ DER Sesudah } & \multicolumn{2}{|c|}{ Selisih } \\
\cline { 3 - 4 } & & \multicolumn{1}{|c|}{ RP } & \multicolumn{1}{c|}{$\%$} \\
\hline 1.29774 & 0.92053 & -0.37721 & -29.07 \\
\hline 0.21305 & 0.23464 & 0.02158 & 10.13 \\
\hline 1.47579 & 1.47166 & -0.00413 & -0.28 \\
\hline 0.15407 & 0.19486 & 0.04078 & 26.47 \\
\hline 0.44582 & 0.42768 & -0.01813 & -4.07 \\
\hline 0.51691 & 0.51775 & 0.00084 & 0.16 \\
\hline 0.52964 & 0.45006 & -0.07958 & -15.03 \\
\hline 0.40111 & 0.49795 & 0.09684 & 24.14 \\
\hline 1.74082 & 2.98148 & 1.24066 & 71.27 \\
\hline 1.55197 & 0.88203 & -0.66993 & -43.17 \\
\hline
\end{tabular}

\begin{tabular}{|l|r|r|}
\hline Mean & DER sebelum & DER sesudah \\
Variance & 0.832691456 & 0.857863528 \\
Observations & 0.371540452 & 0.701728557 \\
Pearson & 10 & 10 \\
Correlation & 0.817896375 & \\
Hypothesized Mean & 0 & \\
Difference & 9 & \\
Df & -0.16315941 & \\
$t$ Stat & 0.436998914 & \\
$P(T<=t)$ one-tail & 1.833112933 & \\
$t$ Critical one-tail & 0.873997827 & \\
$P(T<=$ t) two-tail & 2.262157163 & \\
tCritical two-tail & & \\
\hline
\end{tabular}

Sumber : Data diolah

Dapat dilihat pada Tabel 12 Dari 10 tabel data variabel DER, terdapat 5 data variabel DER Setelah Covid mengalami kenaikan dibandingkan DER Sebelum Covid. Berdasarkan perhitungan yang dilakukan maka diperoleh angka paired t-Test $0.873>0.05$. Kesimpulannya adalah tidak terdapat perbedaan antara DER sebelum dan DER setelah covid.

\section{Harga Saham}

Tabel 13

Harga Saham sebelum Covid dan Harga Saham Setelah Covid

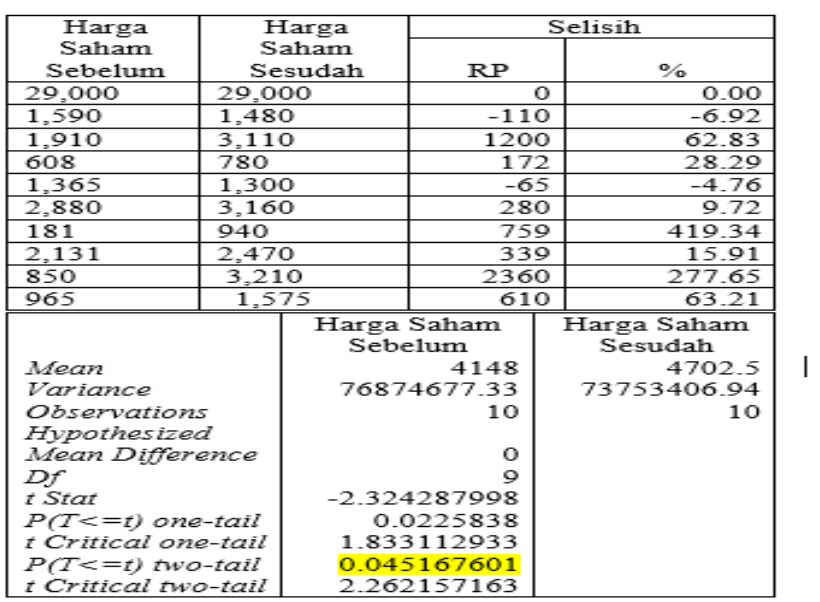

Sumber : Data diolah

Dapat dilihat pada Tabel 13 Dari 10 tabel data variabel Harga Saham, terdapat 8 data variabel Harga Saham Setelah Covid mengalami kenaikan dibandingkan Harga Saham Sebelum Covid. Berdasarkan perhitungan yang dilakukan maka diperoleh angka paired $t$ Test $0.045<0.05$. Kesimpulannya adalah terdapat perbedaan antara Harga Saham sebelum dan Harga Saham setelah covid. 
Hasil Uji Beda Paired Sampel t-test

\begin{tabular}{|c|l|l|}
\hline Rasio & Sig- (2-tailed) & Keterangan \\
\hline CR & 0.155 & Tidak terdapat perbedaan \\
\hline DAR & 0.644 & Tidak terdapat perbedaan \\
\hline ROA & 0.873 & Tidak terdapat perbedaan \\
\hline ROE & 0.538 & Tidak terdapat perbedaan \\
\hline NPM & 0.655 & Tidak terdapat perbedaan \\
\hline EPS & 0.316 & Tidak terdapat perbedaan \\
\hline BV & 0.095 & Tidak terdapat perbedaan \\
\hline HARGA SAHAM & 0.045 & Tidak terdapat perbedaan \\
\hline Sumber : Data diolah & 0.107 & Terdapat perbedaan \\
\hline
\end{tabular}

Dilihat dari Tabel 14 Pada Indikator CR, EPS, BV, DAR, DER, ROA, ROE dan NPM tidak terdapat perbedaan sebelum dan setelah pengumuman covid 19 karena data menunjukkan nilai angka lebih dari nilai signifikansi. Sedangkan pada indikator harga saham terdapat perbedaan sebelum dan setelah pengumuman covid 19 karena data menunjukkan nilai angka dibawah nilai signifakansi.

\section{PEMBAHASAN HASIL PENGUJIAN}

\section{a. Current Ratio}

Berdasarkan hasil penelitian yang telah digunakan menggunakan uji paired sample test, nilai sig CR yaitu $0.243>0.05$, maka dapat disimpulkan bahwa CR sebelum covid dan CR setelah covid menujukan tidak terdapat perbedaan yang signifikan.

b. Debt To Asset Ratio

Hasil penelitian yang telah digunakan dengan menggunakan uji paired sample t test, nilai sig DAR yaitu $0.644>0.05$, hal tersebut menunjukan bahwa DAR sebelum covid dan DAR setelah covid tidak terdapat perbedaan yang signifikan. Pada tabel analisis deskriptif, dilihat dari rata- rata (mean) nilai sig DAR sebelum covid sebesar 0.3995 , sedangkan DAR setelah covid sebesar 0.4073 , maka DAR setelah covid lebih besar. DAR sebelum adanya covid dinilai lebih kecil dibandingkan dengan saat setelah adanya covid. Meskipun demikian, dapat disimpulkan bahwa asset perusahaan dinilai masih mampu membiayai hutang yang dimiliki perusahaan.

\section{c. Return On Asset}

Hasil penelitan yang telah dilakukan dengan menggunakan uji paired sampel t test, dapat diketahui bahwa nilai sig ROA $0.538>0.05$. Dapat dilihat dari nilai tersebut maka tidak terdapat perbedaan yang signifikan antara ROA sebelum covid dan ROA setelah covid. Jika dilihat dari nilai rata-rata (mean) ROA dalam analisis deskriptif, nilai ROA sebelum covid sebesar 0.0817 dan ROA setelah covid 0.0877

\section{d. Return On Equity}

Berdasarkan hasil penelitian yang telah digunakan menggunakan uji paired sample t test, nilai sig yaitu $0.655>0.05$, maka dapat disimpulkan bahwa ROE sebelum covid dan ROE setelah covid menujukan tidak terdapat perbedaan yang signifikan. Dilihat dari nilai ratarata (mean) ROE dalam analisis deskriptif, nilai ROE sebelum covid 0.1220 ROE sebelum covid dan 0.1285 ROE setelah covid. Perusahaan mengalami sedikit kenaikan nilai ROE saat terjadinya peristiwa covid. Dapat diketahui bahwa nilai ekuitas perusahaan terbilang cukup baik karena dalam masa pandemi mengalami sedikit peningkatan 


\section{e. Net Profit Margin}

Berdasarkan hasil penelitian yang telah dilakukan dengan menggunakan uji paired sampel $t$ test , dapat diketahui bahwa nilai sig NPM $0.316>0.05$. Dapat dilihat dari nilai tersebut maka tidak terdapaat perbedaan yang signifikan antara NPM sebelum covid dan NPM setelah covid.Jika dilihat dari analisis deskiptif nilai rata-rata (mean) NPM sebelum covid 0.0856 dan NPM setelah covid 0.1084. nilai NPM lebih meningkat sedikit setelah adanya covid. Perusahaan dinilai masih mampu mendapatkan laba bersih dari penjualan yang telah dilakukan, karena dalam masa pandemi covid masyarakat banyak yang memerlukan obatobatan, maka dari penjualan perusahaan farmasi juga berdampak baik.

\section{f. Earning Per Share}

Berdasarkan hasil penelitian yang telah dilakukan, dapat diketahui bahwa nilai EPS 0.095 $>0.05$. Dapat dilihat dari nilai tersebut maka tidak terdapaat perbedaan yang signifikan antara EPS sebelum covid dan EPS setelah covid. Dapat dilihat bahwa nilai EPS dalam analisis deskriptif dengan nilai rata-rata (mean) EPS sebelum covid sebesar 23.8211 dan EPS setelah covid sebesar 34.7483930. Nilai EPS meningkat saat setelah covid, artinya Perusahaan mendapatkan laba bersih dari setiap jumlah saham yang beredar. Jika nilai EPS naik perusahaan dinilai mampu memperoleh keuntungan, karena banyaknya jumlah saham yang beredar akan mempengaruhi laba perlembarnya.

\section{g. Book Value}

Berdasarkan hasil penelitian yang telah dilakukan dapat diketahui bahwa nilai BV $0.107>$ 0.05. Dapat dilihat dari nilai tersebut maka tidak terdapat perbedaan yang signifikan antara BV sebelum covid dan BV setelah covid. Dapat dilihat bahwa nilai BV dengan nilai ratarata (mean) BV sebelum covid sebesar 221.5498 dan BV setelah covid sebesar 247.6337. Hal tersebut menunjukan angka BV sebelum covid lebih besar. Meskipun dalam pandemi, para investor masih tetap berinvestasi di perusahaan tersebut, maka nilai saham yang terbitkan perusahaan dinilai masih dapat diminati oleh investor.

\section{h. Debt to Equity Ratio}

Hasil penelitian yang dilakukan menunjukan nilai sebesar $0.873>0.05$. Hal tersebut berarti bahwa nilai DER sebelum covid dan DER setelah covid tidak terdapat perbedaan yang signifikan. Jika dilihat dari nilai rata-rata (mean) DER sebelum covid 0.8327 dan DER setelah covid 0.8579. nilai DER lebih besar pada saat setelah covid. Akan tetapi perbedaan nilai tersebut terbilang tidak begitu banyak. Hal tersebut menunjukan bahwa nilai proporsi hutang yang digunakan masih mampu dibiayai oleh ekuitas atau modal perusahaan

\section{i. Harga Saham}

Berdasarkan hasil penelitian yang telah dilakukan dapat diketahui bahwa nilai Harga Saham $0.045<0.05$. Dapat dilihat dari nilai tersebut maka terdapaat perbedaan yang signifikan antara Harga Saham sebelum covid dan Harga saham setelah covid. Jika dilihat dari nilai rata-rata (mean) Harga Saham sebelum covid 4148.0000 dan Harga Saham setelah covid 4702.5000 .

\section{KESIMPULAN}

Berdasarkan penelitian yang telah dilakukan maka dapat disimpulkan sebagai berikut :

a. Berdasarkan hasil pengujian yang telah dilakukan diketahui bahwa kinerja keuangan pada sebelum covid pada tahun 2019 memiliki nilai rata-rata CR sebesar 3.0038, EPS sebesar 23.82 , BV sebesar 221.54, DAR sebesar 0.39, DER sebesar 0.83, ROA sebesar 0.081, ROE sebesar 0.122 , NPM sebesar 0.085 dan Harga Saham sebesar 4148

b. Berdasarkan hasil pengujian yang telah dilakukan diketahui bahwa kinerja keuangan setelah munculnya covid 19 pada tahun 2020 memiliki nilai rata-rata CR sebesar 2.3395, EPS sebesar 34.74, BV sebesar 247.63, DAR sebesar 0.40, ,DER sebesar 0.85, ROA sebesar 0.087, ROE 
sebesar 0.128, NPM sebesar 0.108, dan Harga saham sebesar 4702. Dapat disimpulkan bahwa perusahaan farmasi mengalami peningkatan pada rasio EPS, BV, DAR, DER, ROA, ROE, NPM, dan harga saham. Hanya pada rasio CR mengalami penurunan.

c. Dari hasil pengujian yang telah dilakukan, diketahui bahwa pada Indikator CR,DAR,DER,ROA,ROE, EPS, NPM dan BV tidak terdapat perbedaan yang signifikan, sedangkan untuk Indikator Harga Saham terdapat perbedaan yang sigifikan. Hal tersebut menandakan bahwa perusahaan farmasi memiliki kinerja keuangan yang masih baik. Maka dapat disimpulkan bahwa tidak terdapat perbedaan pada kinerja keuangan sebelum dan sesudah covid.

\section{DAFTAR PUSTAKA}

Referensi Buku :

Arthur J.Keown, et al. 2008. Manajemen Keuangan Edisi Kesepuluh, Jakarta. PT. Indeks

Sugiyono , 2018. Metode penelitian bisnis pendekatan kuantitatif, Kombinasi, dan R\&amp;D Bandung : Alfabeta

Jurnal :

Ambarwati Sri,et al. 2021. Determinan Nilai Perusahaan Sebelum dan Pada Masa Pandemic Covid 19 , Jurnal Becoss

Dito, et al, 2020. Dampak Pandemi Covid-19 terhadap Perekonomian Indonesia, Jurnal Benefita $5(2)$

Evi Kumala, et al, 2021. Pengaruh Pandemi Covid terhadap laporan keuangan Triwulan padaperusahaan LQ45 yang terdaftar di BEI. E-JRI, Vol.10 No.03

Joanne Ve, 2020. Analisis Perbandingan Harga Saham PT Garuda Indonesia Persero (Tbk)sebelum dan sesudah Pandemi Covid 19 pada Perusahaan -Jurnal Administrasi Bisnis (JAB)

Khoiriah, et al , 2020. Pengaruh sebelum dan saat adanya pandemi Covid 19 terhadap harga saham perusahaan LQ45 di BEI . E-JRA,09

Mustika Dwi, 2019. Perbedaan Kinerja Keuangan Perusahaan Dan Pasar Sebelum DanSesudah Tax Amnesty diberlakukan, Unika Soegijapranata Semarang 